\section{Increased and decreased eating following THC administration*}

\author{
STANLEY D. GLICK and SVETLANA MILLOY \\ Herbert M. Singer Laboratory of Neurosciences and Addictive Diseases \\ Bernstein Institute, Beth Israel Medical Center \\ 307 Second Avenue, New York, N.Y. 10003 \\ and \\ Department of Pharmacology \\ Mount Sinai School of Medicine of the City University of New York
} Fifth Avenue and 100th Street, New York, N.Y. 10029

Rats deprived of both food and water for 1 day were administered $\Delta^{9}$-THC $15 \mathrm{~min}$ prior to presentation of food and water. Food and water intake were then measured $2 \mathrm{~h}$ later. A dose of $1.0 \mathrm{mg} / \mathrm{kg}$ of $\mathrm{THC}$ increased food intake, whereas a dose of $2.0 \mathrm{mg} / \mathrm{kg}$ decreased food intake. Water intake decreased with increasing dose.

The results of animal studies with $\triangle 9$-THC have indicated that THC depresses food intake (e.g., Manning, McDonough, Elsmore, Saller, \& Sodetz, 1971). Observations on humans generally show that THC increases food intake or has no effect in either direction (Hollister, 1971). The toxicity associated with the higher doses of THC usually employed in animal studies has recently been emphasized (Elsmore \& Fletcher, 1971). The aim of the present experiment was to determine if increases and decreases in food intake were indeed a result of, respectively, low and high doses of THC.

$$
\text { METHODS }
$$

The Ss were 20 naive female Sprague-Dawley rats weighing $210-240 \mathrm{~g}$. They were housed

Table 1

\begin{tabular}{ccccc} 
& \multicolumn{2}{c}{ Table 1} \\
Mean Food & and Water Consumed & and Weight & Gain \\
\hline $\begin{array}{c}\text { Dose (mg/kg) } \\
\text { of THC }\end{array}$ & & $\begin{array}{c}\text { Water } \\
(\mathrm{ml})\end{array}$ & $\begin{array}{c}\text { Weight } \\
\text { Gain }(\mathrm{g})\end{array}$ \\
\hline 0 (Tween) & Food (g) & 8.5 & 9.3 \\
0.5 & 4.83 & 7.8 & 9.0 \\
1.0 & 5.15 & 7.3 & 9.3 \\
2.0 & $6.67^{*}$ & $2.0 \dagger$ & $2.8 \dagger$ \\
\hline
\end{tabular}

*, + Significant difference from $T$ ween at $p<.05$ and .01 , respectively $(t$ tests). water were made available to all rats. The rats' weights and amounts of food and water consumed were all measured $2 \mathrm{~h}$ later. Weight and water were measured to the nearest gram and milliliter, respective, and food to the nearest $1 / 10 \mathrm{~g}$.

\section{RESULTS}

Table 1 shows that a dose of $1.0 \mathrm{mg} / \mathrm{kg}$ of THC significantly increased food intake, whereas a dose of $2.0 \mathrm{mg} / \mathrm{kg}$ of THC significantly decreased food intake. Only a decrease in water intake was significant at the $2.0-\mathrm{mg} / \mathrm{kg}$ dosage. Similarly, weight gain was significantly depressed only by the highest dose.

\section{DISCUSSION}

These results indicate at least one source of confusion concerning the effects of THC on food intake: the dose-response curve is an inverted- $U$ function. In contrast, THC produced a monotonic depression of water intake, although an increase in water intake with a dose less than $0.5 \mathrm{mg} / \mathrm{kg}$ cannot be ruled out. Further animal studies should be directed towards analyzing the effects of low doses $(\leqslant 1 \mathrm{mg} / \mathrm{kg})$ of THC, since the latter are probably more comparable to doses self-administered by humans. to either food or water for $24 \mathrm{~h}$. Following the deprivation period, the rats were weighed and injected IP with either a dose $(0.5-2.0 \mathrm{mg} / \mathrm{kg})$ of THC in a Tween-80 vehicle or the vehicle alone. The volume injected in all cases approximated $0.1 \mathrm{ml}$. Each rat was injected only once; four to six rats were used for each dosage level. Fifteen minutes after injections, premeasured amounts of food and

\footnotetext{
*This research was supported by NIMH Grant 1 RO 1 MH 21156-01 to S. D. Glick.

\section{REFERENCES}

ELSMORE, T F, \& FLETCHER, G. V. $\Delta$. Tetrahydrocannabinol: Aversive effects in rat at high doses. Science, 1971 , 175, 911-912.

HOLLISTER, L. E. Hunger and appetite after single doses of marihuana, alcohol and dextroamphetamine. Clinical Pharmacology \& Therapeutics, 1971, 12 , 44-49.

JOY, R. T., EMMA, C. P., \& MAYER, J. New rat feeding jar: Use in study of relationships of food intake and body weight. Journal of Applied Physiology, $1967,23,589-590$.

MANNING, F, J., McDONOUGH, J. H., ELSMORE, T. F., SALLER, C., \& SODETZ, F. J. Inhibition of normal growth by chronic administration of $\Delta^{9}$-tetrahydrocannabinol. Science, 1971 , $174,424-426$.
} 